\title{
The effectiveness of PAIKEM strategy in the curriculum of KTSP and 2013 for grade 4 students
}

Peni Nur Hidayati

IAIN Salatiga

pennynurhidayati@gmail.com

DOI: $10.18326 /$ mudarrisa.v10i2.245-268

\begin{abstract}
This research aimed to understand the effectiveness of PAIKEM (Active, Innovative, Creative, Effective, and Enjoyable Learning) strategy in the KTSP (School Based Curriculum) in Madrasah Ibtidaiyah (MI) Ma'arif Gedangan and in the Curriculum of 2013 in MI Ma'arif Mangunsari applied in the $4^{\text {th }}$ Grade students in the academic year of 2016/2017. The curriculum changing gave an impact in education especially on the use of learning strategy for teachers to reach the education goal. This research was descriptive qualitative research which used observation, interview, and documentation as the method to collect the data. It used field research as the research method which was conducted by researcher collaborated with teachers. The research result showed that the use of PAIKEM strategy is more effective when it was used in the curriculum of 2013 than applied in KTSP curriculum. The implementation of PAIKEM strategy in the KTSP curriculum is less effective applied in the classroom. It was proven with the students' interaction in the class. Many students were less active during the learning activities. However, teacher and students as the object of the research could follow the activities which applied PAIKEM strategy in the classroom. From the research result, it can be concluded that PAIKEM strategy can be implemented in KTSP and the curriculum of 2013. The implementation of PAIKEM strategy in the curriculum of 2013 is more effective than in the KTSP curriculum.
\end{abstract}

Keywords: PAIKEM strategy, KTSP, Curriculum of 2013 


\section{INTRODUCTION}

School is one of the education system conducted to help to improve the quality of human resources. School goal is to change students' mindset and creativity because school is one of places to learn and study. On the other hand, the learning process had problem faced by students. Students were sleepy, less active in participating during the learning process, needed long time in completing the task given, and still many more obstacles faced by students during the learning process. To break the obstacles mentioned above, teacher needs teaching strategy which is able to boost students' activeness, creativity, and innovation in the learning process. PAIKEM (Pembelajaran Aktif, Innovatif, Kreatif, Efektif, dan Menyenangkan) or Active, Innovative, Creative, Effective, and Enjoyable Learning strategy is one of strategy which can be implemented in the classroom during learning and teaching process (Indrayati, 2017: 43).

In the PAIKEM Strategy, student is put on the center and has special role in the learning activity (Nugraha et al, 2016:844). Learning activity which employs PAIKEM strategy emphasized participant as the unconscious creatures as the primary school students who are able to understand how important the interaction with the environment that produces experience which was one of humanity which is important to broaden the potential skill made (Suprijono, 2011:11). So that, PAIKEM strategy can be said it is a meaningful learning strategy which is used to develop and help students to build the links between the power of new information from any experience that had been owned and skills 
controlled by students so that students are interested to take part in the learning process.

PAIKEM strategy covers theoretical and practical ability. The theoretical ability covers learning value, theoretical support, classroom level, and learning context. The practice ability covers activities which implements PAIKEM practice (Suprijono, 2011: 11). The implementation of PAIKEM strategy in the learning process employs creativity process to reach the learning goal.

Learning is a combination of human, material, facilities, equipment, and procedure that affects each other to reach the purpose of learning (Hamalik, 2010: 57). Learning should not be separated from teacher, media, instrument, infrastructure, material, and the others which used for learning where the purpose of learning can be achieved. Learning process has some standards and contents; one of them is the curriculum. Lately, education in Indonesia faces curriculum transition from KTSP (School Based Curriculum) to Curriculum of 2013. Curriculum of 2013 launched officially on July 15, 2013 and it has already been carried out from the academic year of 2013/2014 in certain schools which became pilot schools.

In the learning process, Curriculum 2013 uses thematic based learning. Thematic based learning is sourced from Schema theory. Schema theory views human perception and understanding as a combination of previous knowledge and experience with new knowledge and experience as a whole with full meaning (Suwardi, 2017:220). Thematic based learning 


\section{Mudarrisa: Jurnal Kajian Pendidikan Islam, Vol. 10, No. 2, 2018}

is an integrated learning that uses the theme to unify the materials of which there are in some subjects (Kurniasih \& Sani, 2014: 45). There are still many weaknesses in the implementation of the 2013 Curriculum. Looking at the composing the Curriculum of 2013, It looks coercion because the preparation of constructing this curriculum seems impressed and sudden to promote this curriculum. Even though government had already taken public test on changes of the curriculum in several schools around two years, evaluate what can be done, and it is implemented gradually from a certain level of class and a school, yet there still met plenty of many obstacles even refusal from many parties. Because of new concept, it requires preparation and further socialization to the teachers as the leading of education to know and finally they can apply the new curriculum.

The curriculum changing from KTSP to curriculum of 2013 certainly gives an impact to the teaching system both in terms of teaching style and the material, so teaching style turns the approach from the old way to new way, Such as: a) Principle of teaching and learning; b) aspect of students development; c) Respect toward individual student; d) Personal development; e) Methods and teaching techniques; f) the concept of discipline; g) Measurement and evaluation; h) The use of audio visual instrument (Hamalik, 2010:10-13).

The changing of instructions certainly has an impact on the use of teaching strategy done by teachers in order to be able to accomplish a learning goal to maximize the education. Every Education staff should be 
well understood to the purpose of education, where the goals are composed by the progressive education which consists of national target education, the purpose of institution, the purpose of curricular, and the purpose of learning.

Novelty of this research was the improvement of Curriculum of 2013 by using PAIKEM strategy. The use of PAIKEM strategy is to increase student's liveliness in the learning process. The phenomenon of curriculum transition also influences the teaching and learning process for students. It is because school has not ready yet to transform to the new curriculum. It is not surprising that there are still many schools that have not yet ready with the use of a new curriculum especially in adapting and choosing strategies used in the learning process. In this case, the researcher wants to know the effectiveness of using PAIKEM strategy at MI Ma'arif Gedangan with KTSP Curriculum and MI Ma'arif Mangunsari with 2013 Curriculum.

\section{METHODS}

The research method was done in this research adopting both qualitative and field research. The qualitative research was conducted to get something interesting from the descriptions of object observed with a broad and based stout, and provides an explanation of processes occurring in the environment (Maslikhah, 2013:319). The qualitative study is to understand a groove of events in chronological order. The qualitative study that is articulated used also explains the phenomena of the used the 
word and sentence. The research was conducted in MI Ma'arif Gedangan Semarang which implemented school based curriculum (KTSP) and MI Ma'arif Mangunsari Salatiga which implemented 2013 Curriculum. The consideration of choosing the object of research was because it has obtained as the representative of the population in the city.

The researchers used observation technique that applied observation, interview, and documentation as the technique to collect the data. In the qualitative study, the data obtained should be tested its credibility. The credibility of the test data as one of the test which was not influenced by the researchers is identically tested using data validity. To get the validity of the data which corresponds to the finding, the researcher conducted data triangulation technique.

\section{RESULTS AND DISCUSSIONS}

Effective means giving effect (influence, give result, impressed, and afficacious) (Rahma, 2013:11; Stefanidis et al., 2017:11). So, effective means that you can reach the goal you are intended while effectiveness is the connection between expected outcomes with the result that is intended to be achieved. The effectiveness of curriculum cannot be separated with the term, where the curriculum is a system which has components that are interconnected from one to each other. The effectiveness of curriculum is seen from the following components such as: a) goal, b) contents of teaching materials, c) strategy or method, d) organization and, e) evaluation. The curriculum components conducted 
individually as well as together become major foundation to develop learning system in school (Hidayat, 2013:51-68). Curriculum will be less effective if one of the components is not applied because these components have essential part of the curriculum.

Term of strategy was originally used in the world of military which was defined as a way used by all military force to win a war. Now, strategy term is much used in various fields of activity aimed to obtain or reach success for certain objectives (Suyadi, 2013:13). As the developments of the times, learning strategy can be defined as planning that consists of sort of the series of activities designed to achieve certain educational objective. It is expected that good teaching and learning proccess will generate good result in reaching the learning goal.

Learning strategy is a way which will be used by teachers to choose the learning activities that is applied during the learning process (Aqib, 2015:71). The elections was based on the situation and the condition, source of learning, the needs and characteristic of students faced which is intended to achieve certain purpose of learning.

From the concepts above, it can be concluded that learning strategy is planned by the teachers that is given to their students to achieve a particular aim. Learning strategy always corresponds to the components used in the learning process. In choosing a learning strategy, it should also be adjusted to the condition, learning source, necessity, and characteristic of the students. 


\section{Mudarrisa: Jurnal Kajian Pendidikan Islam, Vol. 10, No. 2, 2018}

The implementation of learning strategy will give impact in the learning process. One of learning strategy is PAIKEM strategy which is used by teacher to be implemented in the learning process. The PAIKEM strategy is learning strategy that is constructed to improve student's liveliness in the learning process. KTSP (Kurikulum Tingkat Satuan Pendidikan) is School Based Curriculum which was developed based on the unit of education/school unit, potential/local school, characteristics of the school/regions, local social and cultural community, and characteristic of students. School and school committee, or Islamic School and the Islamic School committee develop the School Based Curriculum (KTSP) and its syllabus based on a fundamental framework of curriculum and competence standards in each school level. KTSP is strategy to develop effective, productive, and well performed school based curriculum. KTSP is new paradigm of curriculum development which gives wider autonomy to school unit, and public involvement to get involve in reaching effective learning process in school (Mulyasa, 2007:20-21).

PAIKEM strategy should be implemented in the KTSP because learning activity in KTSP does not only focuses on teacher but also provides opportunities to the student to be active, creative, innovative in learning activities where teacher only becomes a facilitator while student focuses on the learning process. In the Curriculum of 2013, the use of PAIKEM strategy was advisable to be implemented because this strategy corresponds to the goal of Curriculum of 2013. The keywords usually applied in the Curriculum of 2013 have close relation to the learning 
process. The keywords consist of seven components; spiritual, attitude, social, science, art, sport, and skill.

The keywords is based on UU No. 20 of 2003 on the National Education System, Article 1 No 1 which states that education is a conscious effort and planned to realize the atmosphere of learning and the learning process that primary school students actively develop their potency to energize their spiritual religiosity, self-control, personality, intelligence, noble remembrance, as well as the skills required to themselves, community, people, and their country. Learning process is a unit of interactive education which is inspiring, fun, challenging, motivating students to activate students' participant, and also provides adequate space for the initiative, creativity, and independence based on their talent, interest, and development of students' physical and psychological aspect (Rusman, 2016:72-73).

The implementation of the Curriculum of 2013 in primary school/MI emphasizes on modern dimensions pedagogy in learning that uses scientific approach. Scientific approach is an approach of learning that emphasizes on activity through observing students, questioning, informing, associating/ thinking/ processing information, and presenting/communicating associating material that is delivered in the learning activities at school. Scientific approach is learning approach that gives opportunity to students to broadly conduct an exploration, elaborate a matter, and moreover to give opportunity to the students to actualize ways through the learning designed by teachers. 


\section{Mudarrisa: Jurnal Kajian Pendidikan Islam, Vol. 10, No. 2, 2018}

From the concepts above, it can be concluded that Curriculum of 2013 is a refinement of previous curriculum where Curriculum of 2013 more focuses on competence which is based affective, psychometric, and cognitive aspect. In the other hand, the curriculum still has weaknesses because there are many schools which have not ready yet to change their curriculum. The effectiveness of PAIKEM strategy was shown in KTSP curriculum in MI Ma'arif Gedangan and in MI Ma'arif Mangunsari which implements Curriculum of 2013 where the students of the $4^{\text {th }}$ Grade in the academic year of $2016 / 2017$ as the subject of the research. The researcher applied observation, interview, and documentation when the research conducted the research as the technique to collect the data. The informant of this research was the teachers of $4^{\text {th }}$ grade teachers from each school which was called as the object of research.

Table 1. The Learning Activity in Social Lesson

\begin{tabular}{ll}
\hline Time & \multicolumn{1}{c}{ Activities } \\
\hline 08.30 & Teacher started learning with salaam and took attendance list \\
08.40 & $\begin{array}{l}\text { Teacher gave feedback by asking some previous materials and explained } \\
\text { today's subject. Teacher asked students' history of their environment and } \\
\text { the history which had been known by students }\end{array}$ \\
Teachers explained about relic history and attract students to be actively in \\
the class by asking the example, etc. \\
Teachers gave 15 minutes to students to read the material from the \\
textbooks to enlarge their knowledge outlined by teacher \\
The next step was conducting card short activity which was provided and \\
instructed by teacher. It was started by dividing the group (card short) and \\
sorts the cards into the cards which are included into a relic (inheritance) \\
or a relic of history according to the explanation explained by the teacher \\
before. \\
Teacher confirmed the things which was described and stuck by students \\
and evaluated the activity in 10 minutes \\
After the activity had been done, all students were asked to prepare \\
material which would be learned in the next meeting.
\end{tabular}




\section{Ma'arif Gedangan}

Observation in MI Ma'arif Gedangan was held on tuesday20, 2016 at 08.30-12.30 on social studies lesson with the material history. The teachers did not forget to prepare the media based on the material scheduled. The researchers found result of observation as explained in Table 1.

Besides observing teacher and students role in the class the researcher also observed the students' liveliness in the learning process. The result of observation conducted by researcher in MI Ma'arif Gedangan with total students 24 students showed that students who were active in the class were about 13 students. According to the result of observation which was conducted by the researcher, the learning process is less effective because the teacher focused on lesson plan which had already prepared without creating any variation especially in implementing PAIKEM strategy.

Table 2. The Learning Activity at Art and Culture Lesson

\begin{tabular}{cl}
\hline Time & \multicolumn{1}{c}{ Activities } \\
\hline 10.10 & $\begin{array}{l}\text { Teacher started the learning with salaam and gave appreciation } \\
\text { Teacher sang a song "kring-kring ada sepeda" then the students were asked } \\
\text { to imitate together. } \\
\text { Teacher asked students about the meaning of the song of "kring-kring ada } \\
\text { sepeda", after that, every student should answer and give their opinion } \\
\text { about the song. }\end{array}$ \\
10.40 & $\begin{array}{l}\text { The teachers asked the students whether there were students willing to } \\
\text { come forward to sing without being pointed by teacher. } \\
\text { The teachers found again students were voluntarily coming forward to sing } \\
\text { the song. }\end{array}$ \\
11.10 & $\begin{array}{l}\text { In the end of the class, teacher required students to prepared the next } \\
\text { lesson, and closed the lesson by saying salam }\end{array}$
\end{tabular}




\section{Mudarrisa: Jurnal Kajian Pendidikan Islam, Vol. 10, No. 2, 2018}

After observing the learning process, it showed that students were quite happy because they were involved directly in the learning process through explaining their personal experience, sticking picture cards, and answering the questions given by teacher.

Table 3 .The Learning Activity in Mathematics Lesson

\begin{tabular}{|c|c|}
\hline Time & Activities \\
\hline 11.20 & Teacher opened the lesson by salaam \\
\hline 11.25 & $\begin{array}{l}\text { Teacher asked about the material that was studied a weeks ago and } \\
\text { explained the material learned today }\end{array}$ \\
\hline 11.35 & $\begin{array}{l}\text { Teacher explained about "the change floating to percent" and provided the } \\
\text { example, then teacher asked students if they have already understood the } \\
\text { material or not. There were students who had not understood the material } \\
\text { yet, then teacher reinforced and explained again the material which was } \\
\text { unclear enough. }\end{array}$ \\
\hline 12.00 & $\begin{array}{l}\text { Teacher asked students to observe the material in the students' handout, } \\
\text { then asked students about their understanding. }\end{array}$ \\
\hline 12.10 & Teachers asked them to do exercise and gave the direction to do it. \\
\hline 12.25 & $\begin{array}{l}\text { Teachers together with students concluded the material learned today and } \\
\text { closed the close the class by saying salaam }\end{array}$ \\
\hline 12.30 & Teachers and students prayed together \\
\hline
\end{tabular}

Based on the observation conducted, the implementation of PAIKEM Strategy will run well in the KTSP at MI Ma'arif Gedangan when the teacher as the facilitator understands well not only theoretically but also practically about the PAIKEM strategy. There was precise creativity toward teacher when preparing the media to make it more various and interesting. Based on the research conducted in MI Ma'arif Gedangan, we can conclude that the implementation of PAIKEM strategy in the KTSP curriculum has not optimally effective yet it was because there was no correlation between the needs and students' interests. In addition, the teacher's level of understanding of PAIKEM strategy was still low. 


\section{Ma'arif Mangunsari}

The research conducted in MI Ma'arif Mangunsari was held on Thursday, on September 15, 2016 at 08.30-12.30 a.m. The themes which were taught when the observation at MI Ma'arif Mangunsari conducted were theme 25 which focused on Social (IPS), Mathematics and SBdP, However this discussion would only focus on Social lesson only. Before learning began, teacher was preparing additional media in form of telecast power point through LCD and prepared the audio speaker. After the learning media had been ready, the learning process was started. The description of learning activity was described on Error! Reference source not found..

Table 4. The result of the observation at the theme 2 to theme 5

\begin{tabular}{ll}
\hline Time & \multicolumn{1}{c}{ Activities } \\
\hline 08.30 & $\begin{array}{l}\text { Teacher started learning with salaam, greeted students and took attendance } \\
\text { list }\end{array}$ \\
\hline 08.35 & $\begin{array}{l}\text { Teacher explained the purpose of learning and shared basic competence of } \\
\text { every basic competence of subject. }\end{array}$ \\
\hline 08.40 & $\begin{array}{l}\text { Teacher started the class by giving questions about social class to the } \\
\text { students, then the teacher explained the material, all students listened to } \\
\text { what teacher explained while they were writing the explanation and } \\
\text { occasionally they were given some questions. }\end{array}$ \\
\hline 08.50 & $\begin{array}{l}\text { Teachers gave various activities to the students one of them was playing video } \\
\text { which had close relation to the material that was the process of making some } \\
\text { foods from cassava }\end{array}$ \\
\hline 09.10 & $\begin{array}{l}\text { After playing the video, to make the class more cheerful, female students } \\
\text { were asked to sing a song which was about food discussed. This was also } \\
\text { aimed to make students more understand to the material given. After singing } \\
\text { the song, students were given some questions about the song they had sung. } \\
\text { This questions to know students' understanding about material and the } \\
\text { song. }\end{array}$ \\
\hline 09.25 & $\begin{array}{l}\text { Teacher showed some pictures to the students and they were asked to guess } \\
\text { the use of cassava drawn in the pictures. }\end{array}$ \\
$\begin{array}{l}\text { Students were asked to memorize the material explained by the teacher from } \\
\text { power point text. }\end{array}$
\end{tabular}




\begin{tabular}{ll}
\hline 09.30 & $\begin{array}{l}\text { Teacher divided the class into some groups. To make it fair, teacher divided } \\
\text { the class based on the student number from the attendant list. }\end{array}$ \\
\hline 09.35 & $\begin{array}{l}\text { Teacher instructed students to do group task in } 25 \text { minutes. Teacher also } \\
\text { provided a lecture, gave counseling, and became facilitator. When the } \\
\text { students had done the task, students together with teacher conducted a } \\
\text { discussion about the assignment. }\end{array}$ \\
\hline 09.55 & $\begin{array}{l}\text { Teacher and students drew conclusion from the Social lesson and the } \\
\text { learning process. }\end{array}$ \\
\hline 10.00 & Break \\
\hline 10.10 & $\begin{array}{l}\text { The next lesson was SBdP subject, students were asked to singing together } \\
\text { "kring-kring ada sepeda" song which was presented on power point slide. }\end{array}$ \\
Students sang it together followed with the dance.
\end{tabular}

PAIKEM strategy was applied in the $4^{\text {th }}$ grade students of MI Ma'arif Mangunsari with the total students 35 students. From the research conducted, it is found that the number of students who were actively joining the lesson were 21 students. During the learning activities, teacher had enough creative in designing learning activity to make them more attractive, for example by playing the video related to the lesson, presenting material through power point text, and singing a song which has relation to the lesson so that the learning activity became more attractive.

The implementation of PAIKEM strategy was fully effective implemented in the learning process because teacher did not only focus on the lesson plan prepared but also make some variations which supported 
the learning process. When the learning steps did not attract students to have attention to the lesson, teacher directly created a variation which was matched with the students' characteristics and interest. Observation process was held during the classroom learning process. It was quite pleased because students directly involved in the in the learning process such as; singing together, answering questions given by teacher and having role in dynamic group activities.

Based on the result of observation conducted in MI Ma'arif Mangunsari, it showed that the implementation of PAIKEM strategy in Curriculum of 2013 can be implemented effectively. It is suggested that teacher should enlarge his knowledge about PAIKEM strategy and understand the urgency of implementing PAIKEM strategy. He should continuously apply PAIKEM strategy in the learning activity and improve his creativity in preparing the learning media to make the class more interesting and not boring.

The observation conducted in MI Ma'arif Mangunsari resulted that PAIKEM strategy has been used well in the Curriculum of 2013 that emphasizes on students' liveliness and learning design. In the learning activity, teacher had good creativity in designing attractive learning activity, for example by playing the video during the lesson, preparing material through power point that supported the learning process, and singing song that corresponded to the learning material.

The result of observation also showed that the effectiveness of PAIKEM strategy was maximally implemented in the classroom. It was 
supported with the reality that teacher did not only focus on lesson plan that was prepared before but also make some variation when the teaching steps was not matched with the students' behavior. Students decided to make some learning variation based on the students' need. During the observation, students were described enjoyable and fun joining the classroom activity. They were active in the class because they were involved directly in the classroom activity such as singing together, answering the questions given by teacher and taking part in the dynamics of group activities.

According to the result of observation, PAIKEM strategy obtained maximally when it was implemented in the Curriculum of 2013 at MI Ma'arif Mangunsari. The follow up of this observation is that teacher should extend their understanding and knowledge about PAIKEM strategy and the urgency of this strategy as the effective strategy and continue to apply this strategy in learning activities. The implementation of PAIKEM strategy will be better when teacher could create the learning media creatively to make some variations and avoid boring activity. PAIKEM strategy had been implemented effectively because it corresponds with the concept of Curriculum of 2013 that stresses students' liveliness and teacher's creativity in designing the lesson.

\section{The KTSP curriculum in MI Ma'arif Gedangan}

In addition to the observation conducted in the classroom, the researcher also had an interview with the teacher. The interview was held to Mrs. 
Diyah Rufaidah the $4^{\text {th }}$ grade teacher at MI Ma'arif Gedangan. KTSP curriculum had been implemented in MI Ma'arif Gedangan from 2006 and been maximally implemented by applying EEK concept (Exploration, Elaboration, and Confirmation). KTSP was implemented optimally in this school, the teachers had to adjust the students' condition, provide visual aids that supported the learning activity, and adjust the material which would be taught. The application of KTSP at MI Ma'arif Gedangan was supported with the supporting facilities and infrastructure; the problem faced was about the students' character and behavior in learning. Some of students were slow learners which liked it or lumped it affected the learning process.

The learning strategies

In implementing KTSP at MI Ma'arif Gedangan, the teacher applied any kinds of learning strategy. Sometimes, teacher combined some strategies in a meeting to avoid monotonous and boring situation in the class. PAIKEM Strategy was sometimes used as the strategy in teaching learning process because teacher should adjust the students' condition and the material which will be delivered. The implementation of PAIKEM strategy at the $4^{\text {th }}$ Grade level had run quite well. It is because there was an interaction and cooperation among teacher and students. PAIKEM strategy also gave impact to the students' learning mindset. They thought that learning using PAIKEM strategy was easily to be understood and interesting. 
The effectiveness of applying PAIKEM strategy

The implementation of PAIKEM strategy is quite effective used in KTSP because basically PAIKEM strategy helps students to understand the material and makes learning more interesting. In addition, the implementation of PAIKEM Strategy at MI Ma'arif Gedangan made some changing in the learning situation and mindset such as: students were more active in the class; students responded positively to the classroom activity, students were easier in understanding material and more excited.

Every strategy must have a weakness so does PAIKEM Strategy. From the implementation of PAIKEM strategy at MI Ma'arif Gedangan, students seemed to be less active when they were asked to have a discussion and to come forward to present their task. The general weakness of any strategy is that it cannot be applied in all subjects and material, PAIKEM strategy does too. Based on the implementation of PAIKEM strategy at MI Ma'arif Gedangan, it showed that PAIKEM Strategy was effective only at certain subject and materials.

According to the analysis of interview at MI Ma'arif Gedangan, it can be concluded that the use of any learning strategy will not impact in learning process. The most important thing in choosing learning strategy is that it can make students active, creative, happy, excited, and participate in learning. 


\section{The 2013 Curriculum in MI Ma'arif Mangunsari}

The researcher also conducted interview at MI Ma'arif Mangunsari to know the implementation of PAIKEM strategy in the learning process. The interview was conducted to Mr Syafi'il Abthothi, the $4^{\text {th }}$ grade teacher at MI Ma'arif Mangunsari. The Curriculum of 2013 started to be implemented at MI Ma'arif Mangunsari on 2014 which has been applied at the $1^{\text {st }}$ and $4^{\text {th }}$ Grade. Then, on 2015, MI Ma'arif Mangunsari also started to apply the Curriculum of 2013 at the $3^{\text {rd }}$ and $6^{\text {th }}$ Grade. On 2016, MI Ma'arif Mangunsari started to implement this curriculum to the whole of class. The success of implementing Curriculum of 2013 is not only because of the good concept of Curriculum of 2013 itself but also because of the educational system at MI Ma'arif Mangunsari and the teacher spirit to be better in teaching.

MI Ma'arif Mangunsari was the only MI which applied Curriculum of 2013 at Salatiga. The MI Ma'arif Mangunsari teachers were familiar with the implementation of this curriculum, and evaluation system based on Curriculum of 2013. MI Ma'arif Mangunsari adapted the facilities and infrastructure at MI Gunung Pati to support the implementation of Curriculum of 2013. The implementation of Curriculum of 2013 at MI Ma'arif Mangunsari ran well however there were many obstacles faced. The first problem was about the facility, all classrooms had not yet equipped with the multimedia. The LCD was only installed at the $4^{\text {th }}$ grade classroom. The second problem was that MI Ma'arif Mangunsari did not get any book references for thematic book. To solve the problem, 


\section{Mudarrisa: Jurnal Kajian Pendidikan Islam, Vol. 10, No. 2, 2018}

teacher together with the principles tried to find any references from other sources and supplemented the teaching process with the e-book and files. In this case, MI Ma'arif Mangunsari teachers were forced to be creative to find any resources which fit with the Curriculum of 2013.

The learning strategies

MI Ma'arif Mangunsari used various strategies including PAIKEM strategy in teaching and learning process. Teachers often used such kind of PAIKEM strategy to teach. Teacher often faced monotonous learning activity when the teachers followed all the planning they made. Teacher should make variation and strategy to make the class more cheerful. Lesson plan was the second case, the most important thing was that how to make students become active, cheerful, and comfortable in the learning process. This idea was also implemented when the PAIKEM strategy was implemented in $4^{\text {th }}$ grade of MI Ma'arif Mangunsari. Students turned to be more active, happy, and attractive to the learning process when the PAIKEM strategy was implemented in their class. It was because they did not feel bored with the learning.

The effectiveness of PAIKEM strategy

The implementation of PAIKEM strategy at MI Ma'arif Mangunsari was effective. In the other hand, the changing of psychological condition of students from attractive to be silent, from happy into unhappy, from active into passive and so on made teacher forced their creativity to find interesting activity in the class. 
When the PAIKEM strategy was implemented in the classroom, it gave some advantages to the students such as: students could get involve in the learning activity; it attracted students' curiosity, and students could elaborate their creativity in making craft. Teacher seemed good enough and master well in implementing PAIKEM strategy. Teacher looked for some ideas to make the class more cheerful and not boring such as: asking students to practice directly, asking students to come forward. Teacher tried to combine any strategies when he taught a material. It was adjusted with the students' emotion. To create consistent situation, teacher tried to find any variation to make students always be attractive in the class.

According to the teacher experience in implementing PAIKEM strategy in MI Ma'arif Mangunsari classroom, it was effective teaching using PAIKEM strategy. On the other hand, the result of learning varied resulted from one class to another because the learning result was also influenced by the teacher's creativity in designing the learning activity and how students receive the knowledge.

From the interview conducted, it can be concluded that the implementation of PAIKEM strategy in the learning process is very influential and suggested to be implemented in the classroom because PAIKEM strategy can make students to be active, creative, cheerful, excited and fully participate in the classroom. 


\section{CONCLUSION}

The use of PAIKEM strategy is more effective when it is used in Curriculum of 2013 than KTSP. It can be seen from the result of the observation, interview, and the data which was obtained. The implementation of PAIKEM strategy (active, innovative, creative, effective, and enjoyable learning) could be well implemented by teachers as well as students. The implementation of PAIKEM strategy can be implemented in the school with KTSP as well as in Curriculum of 2013.

The use of PAIKEM strategy in KTSP at MI Ma'arif Gedangan is less effective implemented in learning in the classrooms. It was proven with the lack of the students' role in the learning process where students were less active to join the activity in the classroom. The use of PAIKEM strategy which applies Curriculum of 2013 at MI Ma'arif Mangunsari was more effective applied in the learning process which was implemented in the $4^{\text {th }}$ grade classroom. This was proven with the students' activeness in the learning activities when PAIKEM strategy was applied. It was because the implementation of PAIKEM strategy was supported with teacher's creativity. Hence, it can be suggested that PAIKEM strategy can be an alternative learning strategy which can be implemented in the Curriculum of 2013. In addition, creativity and the students' attitude also influence the success of the learning process using PAIKEM strategy. 


\section{Mudarrisa: Jurnal Kajian Pendidikan Islam, Vol. 10, No. 2, 2018}

\section{REFERENCES}

Hamalik, O. (2010). Kurikulum dan Pembelajaran. Jakarta: PT. Bumi Aksara.

Indrayati. (2017). The Implementation Of PAIKEM Based on ProjectBased Learning and Cooperative Learning. IOSR Journal of Humanities and Social Science, 22(7), 37-43.

Kurniasih, I., \& Berlian Sani. (2014). Implementasi Kurikulum 2013 (Konsep dan Penerapannya). Surabaya: Kata Pena.

Maslikhah. (2013). Melejitkan Kemahiran Menulis Karya Ilmiah Bagi Mahasiswa. Yogyakarta: Trustmedia.

Mulyasa. (2007). Kurikulum Tingkat Satuan Pendidikan: Sebuah Panduan Praktis. Bandung: PT Remaja Rosdakarya.

Nugraha, Purnamasari, I., \& Tanuatmodjo, H. (2016). Interaction between the Type of School and Learning Outcomes in Student's Soft Skills Enhancement through Cooperative Learning Model (Quasi Experiment on Vocational Students in Bandung). Procedia Social and Behavioral Sciences, 219, 838-845.

Rahma, A., \& Dezi Nur. (2013). Efektifitas Pembelajaran Matematika Pada Bab Perkalian Melalui Metode Jarimatika Terhadap Ketuntasan Belajar Siswa Kelas II MI Pabelan Kec.Pabelan Kab. Semarang Tahun Pelajaran 2012/2013 (PTK Kolaboratif). Salatiga: IAIN Salatiga.

Rusman. (2016). Pembelajaran Tematik Terpadu. Bandung: Fajar Interpratama Mandiri.

Sholeh, H. (2013). Pengembangan Kurikulum Baru. Bandung:Remaja Rosdakarya

Stefanidis, D., Anton, N. E., Howley, L. D., Bean, E., Yurco, A., Pimentel, M. E., \& Davis, C. K. (2017). Effectiveness of a comprehensive mental skills curriculum in enhancing surgical performance: Results of a randomized controlled trial. American Journal of Surgery, 213(2), 318-324.

Suprijono, A. (2009). Cooperative learning teori $\mathcal{E}$ aplikasi PAIKEM. Yogyakarta:Pustaka Pelajar.

Suwardi, Anitah, W. S., Akhyar, M. \& Asrowi. (2017). Gender Bias in Islamic Textbooks for Muslim Children in Indonesia. Attarbiyah: Journal of Islamic Culture and Education. 2(2). 214-235. 
Mudarrisa: Jurnal Kajian Pendidikan Islam, Vol. 10, No. 2, 2018

Suyadi. (2013). Libas Skripsi dalam 30 Hari. Jogjakarta: Diva Press.

Zainal, A. (2015). Model-Model, Media, dan Strategi Pembelajaran Kontekstual (Inovatif). Bandung: Penerbit Yrama Widya. 